\title{
Potensi Maggot (Black Soldier Fly) sebagai Pakan Ternak di Desa Miri Kecamatan Kismantoro Wonogiri
}

\author{
Sholahuddin*, Ato Sulistya, Retno Wijayanti, Supriyadi, Subagiya \\ Program Studi Agroteknologi, Fakultas Pertanian, Universitas Sebelas Maret Surakarta \\ *Corresponding Author : sholahuddin@staff.uns.ac.id \\ Dikirim: 20-10-2020; Diterima: 09-12-2021
}

\begin{abstract}
ABSTRAK
Budidaya ternak ayam dan lele merupakan bidang usaha yang banyak dilakukan oleh warga Desa Miri, Kecamatan Kismantoro, Kabupaten Wonogiri. Tingginya komponen biaya pakan berakibat pada rendahnya keuntungan. Selama ini, peternak masih mengandalkan pelet sebagai pakan utama untuk ternaknya. Pakan alternatif berupa larva Black Soldier Fly (BSF) atau maggot sudah dikenal warga, namun hanya beberapa warga yang pernah menggunakan maggot sebagai pakan. Warga belum pernah mendapatkan edukasi dan pelatihan budidaya maggot. Kegiatan ini bertujuan untuk meningkatkan pengetahuan dan keterampilan warga Desa Miri dalam budidaya maggot, ketergantungan peternak pada pakan buatan dapat berkurang dan digantikan dengan pakan hasil budidaya maggot. Kegiatan yang dilakukan dalam pengabdian terdiri atas sosialisasi dan pelatihan budidaya maggot. Sosialisasi berupa paparan manfaat dan perbanyakan maggot, sedangkan materi pelatihan adalah praktik pemerangkapan telur, pemeliharaan maggot, dan cara panen maggot. Hasil kegiatan menunjukkan adanya peningkatan pengetahuan peserta terkait budidaya maggot sebesar $21,32 \%$. Peserta juga menunjukkan ketertarikan saat melaksanakan kegiatan praktik. Manfaat budidaya BSF diantaranya mengurangi limbah sampah rumah tangga, menghasilkan maggot sebagai pakan ternak, dan menghasilkan pupuk organik.
\end{abstract}

Kata kunci: budidaya maggot, Hermetia illucens, sosialisasi

\section{Potential of Maggot (Black Soldier Fly) as Animal Feed in Miri Village Kismantoro Wonogiri}

\begin{abstract}
Cultivation of chicken and catfish was a field of business that was mostly carried out by residents of Miri Village, Kismantoro District, Wonogiri Regency. The high component of feed costs results in low profits. So far, farmers still rely on pellets as the main feed for their livestock. Alternative feeds in the form of Black Soldier Fly (BSF) larvae or maggot were well known to residents, but only a few residents had ever used maggot as feed. Residents had never received education and training on maggot cultivation. This activity aims to increase the knowledge and skills of Miri Village residents in maggot cultivation, the dependence of farmers on artificial feed can be reduced and replaced with feed from maggot cultivation. Activities carried out in the service consist of socialization and training on maggot cultivation. The socialization was in the form of exposure to the benefits and propagation of maggots, while the training materials were the practice of catching eggs, maintaining maggots, and harvesting maggots. The results of the activity showed an increase in participants' knowledge regarding maggot cultivation by $21.32 \%$. The participants also showed interest in carrying out practical activities. The benefits of BSF cultivation include reducing household waste, producing maggots as animal feed, and producing organic fertilizer.
\end{abstract}

Keywords: Hermetia illucens, maggot cultivation, socialization 


\section{PENDAHULUAN}

Peternakan merupakan usaha potensial untuk pemenuhan kebutuhan daging dan protein hewani. Ekonomi masyarakat Indonesia diproyeksikan mengalami pertumbuhan sebesar $5,2 \%$ setiap tahun khususnya ayam (Rambet et al., 2016). Selain daging dan ayam, untuk mencukupi kebutuhan protein hewani, masyarakat juga mengkonsumsi ikan lele. Berdasarkan penelitian Ciptawati et al. (2021), ikan lele memiliki kandungan protein yang tinggi yaitu sebesar 260,76 mg. Dalam usaha peternakan dan budidaya lele, pakan merupakan faktor utama yang menentukan keberhasilan produk. Pakan pellet merupakan pakan andalan yang dipilih peternak dalam usaha peternakan lele, akan tetapi harga pellet yang cukup mahal mengakibatkan meningkatnya biaya produksi. Berbagai upaya dilakukan untuk menurunkan biaya pakan, salah satunya adalah menggunakan pakan alternatif.

Permasalahan pakan ternak ayam dan lele dialami oleh warga Desa Miri, Kecamatan Kismantoro, Kabupaten Wonogiri. Dalam melakukan usaha peternakan ayam dan budidaya ikan lele, memerlukan pakan yang tidak sedikit. Kebutuhan pakan untuk memelihara ayam sebanyak 100 ekor per hari adalah pellet sebanyak $15 \mathrm{~kg}$ dan bekatul sebanyak $10 \mathrm{~kg}$. Adapun kebutuhan pakan ikan untuk 11 kolam adalah pellet sebanyak $15 \mathrm{~kg}$ dan dedaunan 15 $\mathrm{kg}$ per hari. Jika harga pelet Rp10.000/kg dan bekatul Rp5.000/kg maka biaya untuk 100 ekor ayam mencapai Rp200.000/hari.

Mengingat tingginya biaya pakan, maka diperlukan alternatif pakan berupa maggot atau larva dari Black Soldier Fly (BSF). Maggot yang dibudidayakan dapat digunakan sebagai sumber protein hewani. Selama ini, beberapa peternak sudah memanfaatkan maggot sebagai pakan ayam, namun menemui kendala dalam budidayanya.

Black Soldier Fly, Hermetia illucens (Diptera : Stratiomyidae) adalah serangga asli Amerika namun saat ini telah menyebar ke berbagai belahan bumi termasuk daerah tropis dan subtropis (Rhode et al., 2020). Serangga ini mengalami siklus hidup mulai telur lalu tumbuh menjadi larva (maggot) kemudian menjadi pupa, dan selanjutnya menjadi serangga dewasa (Moretta et al., 2020). Maggot mengandung protein pada kisaran 40-50\% dan lemak 29-32\% (Bosch et al., 2014). Maggot memiliki beberapa keunggulan dibandingkan spesies serangga lainnya, yaitu memiliki aktivitas enzim amilase, lipase, dan protease yang tinggi (Fonseca et al., 2017). Tingginya kandungan nutrisi maggot, menjadikan serangga ini potensial sebagai pakan alternatif untuk ternak. Maggot merupakan sumber protein yang menjanjikan untuk pakan unggas (Schiavone et al., 2017).

Maggot BSF berpotensi digunakan sebagai pakan ternak, mengingat kandungan protein yang tinggi. Namun demikian di Desa Miri, Kecamatan Kismantoro, Wonogiri hanya beberapa peternak ayam dan pelaku budidaya lele yang sudah memanfaatkan maggot sebagai sumber pakan. Hal ini karena terbatasnya pengetahuan peternak dalam teknik budidaya maggot. Kegiatan yang dilakukan bertujuan meningkatkan pengetahuan dan keterampilan warga Desa Miri dalam budidaya maggot. Diharapkan, hasil akhir dari kegiatan ini, ketergantungan peternak pada pakan buatan dapat dikurangi dan digantikan dengan pakan hasil budidaya maggot.

\section{METODE}

Kegiatan pengabdian dilaksanakan di Desa Miri, Kecamatan Kismantoro, Wonogiri pada Bulan April 2020 sampai September 2020. Adapun tahapan kegiatan terdiri atas koordinasi, sosialisasi, dan paparan teknik budidaya maggot, selanjutnya dilakukan praktik demonstrasi budidaya maggot dan monitoring.

Sebelum pelaksanaan sosialisasi, dilakukan koordinasi antara tim pengabdian dan ketua kelompok ternak secara daring untuk menjadwalkan waktu dan tempat pelaksanaan kegiatan, jumlah peserta, bahan, dan peralatan yang dibutuhkan dalam kegiatan.

\section{Sosialisasi dan pemaparan manfaat maggot sebagai pakan ternak}

Kegiatan ini diikuti peternak ayam dan lele dari Desa Miri, Kecamatan Kismantoro, Kabupaten Wonogiri. Materi yang disampaikan terkait pengenalan maggot meliputi: kandungan nutrisi, manfaat, kendala dalam budidaya, teknik pemerangkapan, dan pemanenan. Pemaparan materi disampaikan oleh narasumber yang mempunyai usaha budidaya maggot dan sudah memiliki pengalaman budidaya maggot selama 2 tahun. Selain itu, narasumber juga sudah sering memberikan pelatihan budidaya maggot di beberapa kelompok peternak 


\section{Praktik/demonstrasi budidaya maggot}

Praktik atau demonstrasi dilakukan langsung oleh peserta kegiatan dipandu narasumber. Dalam kegiatan ini peserta mempraktikkan cara pemerangkapan telur lalat BSF, penyiapan media pakan untuk maggot, dan cara pemanenan maggot. Peserta juga dibekali bahan dan peralatan berupa wadah dan pakan, maggot dan pupa, dan kurungan imago untuk budidaya mandiri.

\section{Monitoring kegiatan}

Keberhasilan kegiatan sangat didukung oleh peran semua peserta pelatihan. Untuk mengetahui keberhasilan kegiatan, dilakukan monitoring pasca pelatihan. Dalam monitoring akan dilihat keberhasilan pemeliharaan maggot dan keberlanjutan budidaya BSF yang dilakukan peserta secara mandiri.

\section{HASIL DAN PEMBAHASAN}

Sosialisasi dan pemaparan manfaat BSF sebagai pakan ternak

Kegiatan sosialisasi penyuluhan dan pelatihan diikuti oleh 15 orang peternak ayam dan pembudidaya lele. Semua peserta adalah laki-laki dengan kisaran usia 20-60 tahun. Kegiatan dilakukan secara luring dengan tetap mematuhi protokol kesehatan. Tempat pelatihan di rumah salah satu warga yang mempunyai usaha ternak unggas ayam kampung +/- 100 ekor dan perikanan lele sebanyak 7 kolam cor batako dan 4 kolam terpal dengan isi ikan lele antara 2000-5000 ekor per kolam. Untuk mengetahui keberhasilan penyuluhan, maka dilakukan pretest sebelum dan post-test setelah kegiatan.

Terjadi peningkatan nilai pre-test dan post-test pada semua parameter penilaian (Gambar 1). Rata-rata nilai pre-test 69,34 sedangkan post-test 90,66. Kuesioner yang diberikan sebanyak 5 pertanyaan terkait budidaya BSF secara umum (Tabel 1).
Berdasarkan Tabel 1, sejumlah peserta $(33,3 \%)$ saat pre-test menganggap lalat BSF sama dengan lalat hijau, sebanyak $33,3 \%$ peserta belum mengetahui kalau maggot merupakan stadia pradewasa atau larva BSF. Sebagian besar peserta $(66,7 \%)$ belum mengetahui kalau media terfermentasi dapat digunakan untuk memerangkap telur BSF. Namun, semua peserta sudah mengetahui kalau maggot dapat digunakan sebagai pakan ternak. Secara umum, terjadi peningkatan pengetahuan peserta pelatihan budidaya yang ditunjukkan dengan peningkatan jawaban benar sebesar 21,32\%.

Merujuk pada hasil pre-test, maka materi yang diberikan meliputi pengenalan lalat BSF, manfaat budidaya maggot, jenis pakan maggot, biologi maggot (meliputi ciri-ciri maggot BSF, lama siklus hidup, kemampuan reproduksi BSF), teknik pemerangkapan telur, cara perbanyakan maggot, dan kendala dalam budidaya maggot. Penyampaian materi dengan bantuan slide proyektor dan contoh spesimen. Setelah penyampaian materi dilakukan diskusi dan tanya jawab.

Penyampaian materi diawali dengan pengenalan lalat BSF. Black Soldier Fly merupakan lalat yang banyak ditemukan di alam yang berbeda jenisnya dengan lalat hijau.

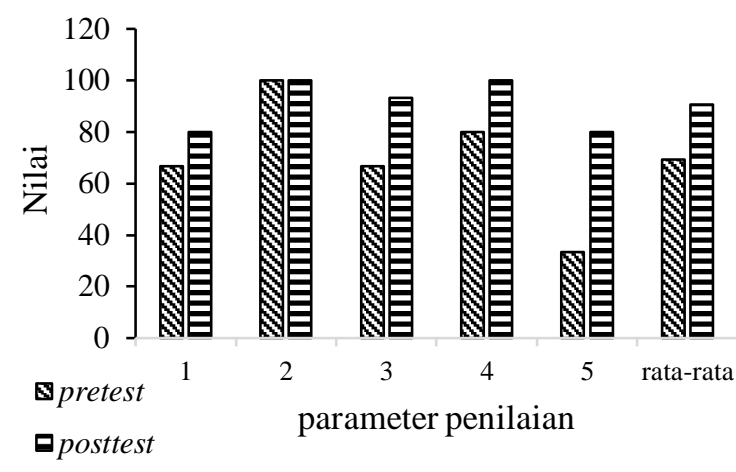

Gambar 1. Nilai pre-test dan post-test budidaya lalat BSF

Tabel 1. Hasil pre-test dan post-test peserta pelatihan budidaya BSF

\begin{tabular}{|c|c|c|c|c|c|}
\hline \multirow{2}{*}{ No } & \multirow{2}{*}{ Pertanyaan } & \multicolumn{2}{|c|}{ Pre-test (\%) } & \multicolumn{2}{|c|}{ Post-test (\%) } \\
\hline & & Benar & Salah & Benar & Salah \\
\hline 1 & BSF beda dengan lalat hijau pemakan bangkai? & 66,7 & 33,3 & 80 & 20 \\
\hline 2 & Maggot BSF dapat digunakan sebagai pakan ternak? & 100 & 0 & 100 & 0 \\
\hline 3 & Maggot adalah pradewasa dari lalat BSF? & 66,7 & 33,3 & 93,3 & 6,7 \\
\hline 4 & $\begin{array}{l}\text { Keberhasilan hidup maggot sangat dipengaruhi oleh jenis } \\
\text { pakan }\end{array}$ & 80 & 20 & 100 & 0 \\
\hline \multirow[t]{2}{*}{5} & $\begin{array}{l}\text { Umpan untuk mendapatkan telur lalat BSF adalah bahan } \\
\text { organik terfermentasi? }\end{array}$ & 33,3 & 66,7 & 80 & 20 \\
\hline & Rata-rata & 69,34 & 30,66 & 90,66 & 9,34 \\
\hline
\end{tabular}


Lalat BSF berwarna hitam, tubuh kekar dengan panjang 15-20 mm, sepintas lalat ini mirip tawon (Maslo et al., 2017). Lalat betina tertarik pada bau fermentasi dari bahan organik untuk bertelur. Pada penyuluhan ini, contoh media perangkap berasal dari limbah sayuran dan bekatul yang ditambah EM-4. Setelah beberapa hari, telur yang diletakkan oleh lalat betina akan menetas dan menjadi maggot. Seekor lalat betina mampu menghasilkan 500 butir telur dan menetas dalam 4 hari untuk menjadi larva maggot (Wahyuni et al., 2017). Larva atau maggot akan memakan bahan organik. Menurut Gunawan et al. (2018), bahan organik adalah sumber makanan dan tempat hidup larva maggot. Keberhasilan hidup maggot sangat dipengaruhi oleh tempat hidupnya. Hasil dan kandungan nutrisi pada maggot sangat bergantung dengan media pertumbuhannya (Cicilia \& Susila, 2018).

Maggot merupakan serangga dekomposer yang sangat penting selain sebagai pakan ternak. Menurut Moula et al., (2018), maggot dapat digunakan sebagai pakan ternak maupun dekomposer bahan organik. Maggot mengandung protein yang cukup tinggi sebesar 45-50\% dan lemak 24-30\% (Fahmi, 2015). Nutrisi maggot yang tinggi berpotensi sebagai pakan unggas dan ikan (Mokolensang et al., 2018; Odjo et al., 2019; Rambet et al., 2016). Manfaat lain dari maggot adalah sebagai pengurai bahan organik yang mampu mereduksi 35-45\% massa limbah (Diener et al., 2009). Produk tambahan dari budidaya maggot adalah limbah media hidupnya yang berupa kompos sebagai pupuk organik (Čičková et al., 2015).

Media pakan yang digunakan sangat berpengaruh terhadap keberhasilan hidup maggot. Kelembaban media berpengaruh terhadap kemampuan menghasilkan telur. Imago betina akan bertelur pada kelembaban lebih dari 60\% (Gou et al., 2020). Keberhasilan hidup maggot sangat dipengaruhi oleh kondisi media pertumbuhannya. Suhu media untuk pertumbuhan maggot yaitu $27-30^{\circ} \mathrm{C}$ dan maggot tidak bertahan hidup pada suhu di atas $36^{\circ} \mathrm{C}$. Nilai $\mathrm{pH}$ media untuk pertumbuhan maggot berkisar antara $6,5-7,5$. Kondisi media yang lembab namun tidak basah (berair) sesuai untuk pertumbuhan maggot (Septiawati et al., 2021).

Kendala yang dihadapi peternak dalam budidaya BSF diantaranya adalah tingkat kematian maggot/larva yang tinggi. Penyebab kematian maggot antara lain media yang terlalu panas, becek, dan bau. Media yang terlalu panas akan menyebabkan matinya maggot-maggot kecil. Media panas dapat terjadi karena populasi maggot dan media terlalu padat sehingga uap tidak bisa keluar. Hal ini mengakibatkan suhu media naik dan terjadi kematian maggot. Kematian maggot juga terjadi saat media terlalu becek karena pakan yang berlebih atau pakan terlalu basah saat diberikan. Bau busuk dari media terjadi karena adanya mikroorganisme.

Kendala lain yang sering ditemui oleh pemula adalah kesulitan dalam pemerangkapan telur BSF dan kerusakan maggot karena diganggu semut. Semut akan datang jika pakan yang diberikan mempunyai rasa manis seperti limbah kulit umbi cilembu. Salah satu cara untuk menghilangkan gangguan semut dengan memberi pakan dari limbah sawi, wortel, kubis, dan gedebog pisang. Jika media pemeliharaan sudah didatangi semut, maka media harus dijemur. Sinar matahari menyebabkan maggot berada di bagian bawah media sehingga mudah diambil dan dipisahkan dari semut. Dalam sosialisasi ini juga dijelaskan cara pemerangkapan telur menggunakan bilah-bilah kayu atau karton yang dipotong melintang dan diletakkan di atas wadah pakan umpan.

\section{Praktik/demonstrasi budidaya BSF}

Setelah mengikuti sosialisasi, peserta melakukan praktik budidaya maggot didampingi narasumber dan tim pengabdian. Bahan praktik meliputi media pakan, berbagai stadia maggot, wadah pemeliharaan, dan kurungan imago. Stadia BSF berupa telur, larva/maggot, pupa, dan imago/dewasa. Tahap awal dari kegiatan ini adalah pengenalan media pakan. Media pakan yang digunakan saat praktik terdiri atas bekatul dan ampas kelapa. Media tersebut digunakan karena dapat meningkatkan biomassa maggot (Odjo et al., 2019). Berdasarkan hasil penelitian Syahrizal et al., (2014), kombinasi media ampas kelapa dan bekatul menghasilkan rata-rata produksi maggot tertinggi yaitu 262,67 g dengan kandungan nutrisi maggot terbaik yaitu protein kasar $50,03 \%$, air $76,44 \%$, abu $8,61 \%$, lemak kasar $20,57 \%$ dan serat kasar 8,45\%. Media pakan tersebut dicampur kemudian dimasukkan dalam wadah pemeliharaan. Pada pelatihan ini, bibit yang digunakan adalah maggot yang berumur 5 hari dan telur BSF.

Maggot dipanen setelah berumur dua minggu atau berukuran sekitar 2,5 $\mathrm{cm}$. Maggot 
yang berumur 14 hari dapat dipanen dan

digunakan sebagai pakan (Rizki et al., 2017).

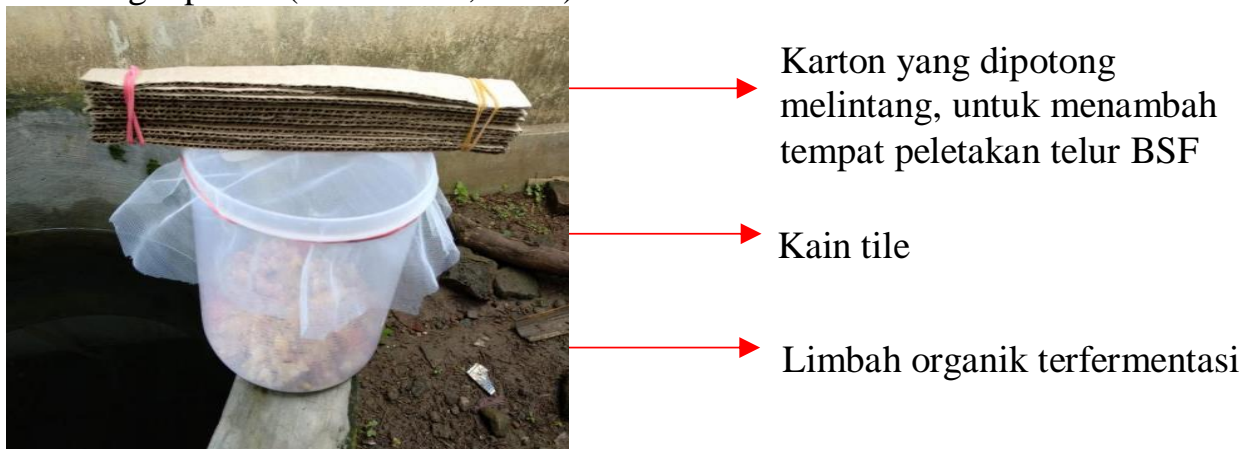

Gambar 2. Perangkap telur BSF

Perlakuan sebelum pemanenan yaitu media ditaburi dengan bekatul untuk mengurangi kelembaban dan menjadikan media kering namun remah. Pada kondisi tersebut, maggot akan mengumpul di dasar wadah. Prosedur pemanenan yaitu: 1) Mengambil media pakan yang ada di bagian atas sedikit demi sedikit sampai hampir seluruh media terambil, 2) Mengayak maggot untuk membersihkan maggot dari media pakan, pengayakan dilakukan 2-3 kali, 3) Hasil maggot yang diperoleh siap digunakan untuk pakan ternak.

Kegiatan praktik pemerangkapan telur dilakukan dengan meletakkan potongan karton tebal di atas wadah pakan terfermentasi (Gambar 2). Bau fermentasi akan menarik datangnya lalat BSF untuk meletakkan telur di antara lubanglubang bilah karton. Jika lubang pada karton sudah berisi telur, maka diganti dengan karton baru sedangkan karton berisi telur dipindah ke media pemeliharaan. Kesalahan yang banyak dilakukan pemula dalam pemerangkapan telur adalah hanya menggunakan wadah berisi media terfermentasi tanpa menyediakan tempat bertelur. Dalam kegiatan ini pakan yang digunakan adalah limbah sayuran yang dicampur bekatul dan EM-4.

\section{Monitoring kegiatan}

Tim pengabdian melakukan pemantauan secara berkala untuk mengetahui perkembangan hasil praktik budidaya maggot. Berhubung kegiatan dilakukan di masa pandemi Covid 19, maka pemantauan dilakukan secara online melalui aplikasi whatsApp atau video call. Hasil pemantauan menunjukkan bahwa sebagian besar peserta berhasil memanen maggot dan memerangkap telur. Maggot yang dipanen telah digunakan sebagai pakan ayam dan lele. Berdasarkan hasil pengamatan tim pengabdian, peserta antusias dan komitmen untuk melanjutkan budidaya BSF. Peserta menganggap budidaya BSF dapat dilakukan dengan mudah dengan waktu panen yang cepat. Budidaya maggot limbah sampah rumah tangga dapat diolah dengan hasil samping kompos sebagai pupuk organik. Dengan demikian budidaya maggot juga mendatangkan keuntungan ekologi berkaitan dengan perannya sebagai dekomposer. Budidaya maggot akan mengurangi limbah sampah organik baik sampah pasar maupun rumah tangga.

\section{KESIMPULAN}

Kegiatan pengabdian budidaya maggot diikuti 15 orang warga Desa Miri, Kecamatan Kismantoro, Wonogiri. Kegiatan terdiri atas sosialisasi, praktik, dan monitoring. Terdapat peningkatan pengetahuan peserta berkenaan dengan budidaya BSF sebesar $21,32 \%$. Peserta pengabdian antusias mengikuti kegiatan praktik budidaya BSF. Keuntungan dari budidaya BSF adalah mengurangi limbah sampah organik, mendapatkan sumber pakan ternak, dan mendapatkan kompos sebagai pupuk organik.

\section{UCAPAN TERIMA KASIH}

Kegiatan pengabdian dibiayai dari sumber dana PNBP UNS Tahun Anggaran 2020 skema Hibah Riset Grup dengan Nomor Kontak 453/UN27.21/PN/2020

\section{DAFTAR PUSTAKA}

Bosch, G., Zhang, S., Oonincx, D., \& Hendriks, W. (2014). Protein quality of insects as potential ingredients for dog and cat foods. Journal of Nutritional Science, 3(29), $1-4$. https://doi.org/10.1017/jns.2014.23 
Cicilia, A. P., \& Susila, N. (2018). Potential of tofu dregs on the production of maggot (Hermetia illucens) as a source of protein of fish feed. Anterior Journal, 18(1), 4047.

https://doi.org/10.33084/anterior.v18i1.4 07

Čičková, H., Newton, G. L., Lacy, R. C., \& Kozánek, M. (2015). The use of fly larvae for organic waste treatment. Waste Management, $\quad 35, \quad 68-80$. https://doi.org/10.1016/j.wasman.2014.09 .026

Ciptawati, E., Budi, I., Oktiyani, H., \& Alvionita, M. (2021). Analisis perbandingan proses pengolahan ikan lele terhadap kadar nutrisinya. Indonesian Journal of Chemical Analysis, 4(1), 4046.

https://doi.org/10.20885/ijca.vol4.iss1.art 5

Diener, S., Zurbrügg, C., \& Tockner, K. (2009). Conversion of organic material by Black Soldier Fly larvae: establishing optimal feeding rates. Waste Management \& Research, 27(6), 603-610. https://doi.org/10.1177/0734242X091038 38

Fahmi, M. R. (2015). Optimalisasi proses biokonversi dengan menggunakan minilarva Hermetia illucens untuk memenuhi kebutuhan pakan ikan. Prosiding Seminar Nasional Masyarakat Biodiversitas Indonesia, $\quad 1(1), \quad 139-144$. https://smujo.id/psnmbi/article/view/1054

Fonseca, K., Dicke, M., \& van Loon, J. (2017). Nutritional value of the Black Soldier Fly (Hermetia illucens L.) and its suitability as animal feed. Journal of Insects as Food and Feed, 3(2), 105-120. https://doi.org/10.3920/JIFF2016.0055

Gou, Y., Quandahor, P., Zhang, K., Guo, S., Zhang, Q., Liu, C., \& Coulter, J. A. (2020). Artificial diet influences population growth of the root maggot Bradysia impatiens (Diptera: Sciaridae). Journal of Insect Science, 20(5), 1-7. https://doi.org/10.1093/jisesa/ieaa123

Gunawan, A., Erlina, S., Samudera, R., Syarif, M., Noor, M., \& Lantu, A. (2018). Effect of supplement maggot Black Soldier Fly live on the percentage of carcass and weight of carcass of male Alabio ducks. IOP Conf. Series: Earth and Environmental Science, 207(1). https://doi.org/10.1088/1755-

1315/207/1/012021

Maslo, B., Valentin, R., Leu, K., Kerwin, K., Hamilton, G. C., Bevan, A., Fefferman, N. H., \& Fonseca, D. M. (2017). Chirosurveillance: The use of native bats to detect invasive agricultural pests. PLoS ONE, 12(3), 1-10. https://doi.org/10.1371/journal.pone.0173 321

Mokolensang, J., Hariawan, M., \& Manu, L. (2018). Maggot (Hermetia illunces) sebagai pakan alternatif pada budidaya ikan. Budidaya Perairan September, 6(3), 32-37.

https://doi.org/10.35800/bdp.6.3.2018.28 126

Moretta, A., Salvia, R., Scieuzo, C., Somma, A. Di, Vogel, H., Pucci, P., Sgambato, A., Wolff, M., \& Falabella, P. (2020). A bioinformatic study of antimicrobial peptides identified in the Black Soldier Fly (BSF) Hermetia illucens (Diptera: Stratiomyidae). Scientific Reports, 10, 114. https://doi.org/10.1038/s41598-02074017-9

Moula, N., Scippo, M., Douny, C., Degand, G., Dawans, E., Cabaraux, J., Hornick, J., Medigo, R. C., Leroy, P., Francis, F., \& Detilleux, J. (2018). Performances of local poultry breed fed Black Soldier Fly larvae reared on horse manure. Animal Nutrition, 4(1), 73-78. https://doi.org/10.1016/j.aninu.2017.10.0 02

Odjo, I., Djihinto, G., Vodounnou, D., Djissou, A., \& Clément, B. (2019). Organic waste management for the maggots production used as source of protein in animal feed. International Journal of Fisheries and Aquatic Studies, 7(2), 122-128.

Rambet, V., Umboh, J., Tulung, Y., \& Kowel, YHS. (2016). Kecernaan protein dan energi ransum broiler yang menggunakan tepung maggot (Hermetia illucens) sebagai pengganti tepung ikan. Jurnal Zootek, $36(1)$. https://doi.org/10.35792/zot.36.1.2016.93 14

Rhode, C., Badenhorst, R., Hull, K. L., Greenwood, M. P., Merwe, A. E. B. Der, Andere, A. A., Picard, C. J., \& Richards, C. (2020). Genetic and phenotypic consequences of early domestication in black soldier flies (Hermetia illucens). 
Animal Genetics, 51(5), 752-762. https://doi.org/10.1111/age.12961

Rizki, S., Hartami, P., \& Erlangga. (2017). Tingkat densitas populasi maggot pada media tumbuh yang berbeda. Acta Aquatica, 4(1), 21-25. https://doi.org/10.29103/aa.v4i1.319

Schiavone, A., Marco, M. De, Martínez, S., Dabbou, S., Renna, M., Madrid, J., Hernandez, F., Rotolo, L., Costa, P., Gai, F., \& Gasco, L. (2017). Nutritional value of a partially defatted and a highly defatted Black Soldier Fly larvae (Hermetia illucens L.) meal for broiler chickens : apparent nutrient digestibility, apparent metabolizable energy and apparent ileal amino acid digestibility. Journal of Animal Science and Biotechnology, $\quad 8, \quad 1-9$. https://doi.org/10.1186/s40104-0170181-5

Septiawati, R., Astriani, D., \& Ariffianto, M. (2021). Pemberdayaan ekonomi masyarakat melalui pengembangan potensi lokal budidaya Black Soldier Fly (maggot) di Desa Sukaratu Karawang. AlKharaj: Jurnal Ekonomi, Keuangan \& Bisnis Syariah, 3(2), 219-229. https://doi.org/10.47467/alkharaj.v3i2.33 9

Syahrizal, Ediwarman, \& Ridwan, M. (2014). Kombinasi limbah kelapa sawit dan ampas tahu sebagai media budidaya maggot (Hermetia illucens) salah satu alternatip pakan ikan. Jurnal Ilmiah Universitas Batanghari Jambi, 14(4), 108-113.

Wahyuni, S. R. I., Supartha, I. W., Ubaidillah, R., \& Wijaya, I. N. (2017). Parasitoid community structure of leaf miner Liriomyza spp. (Diptera : Agromyzidae) and the rate of parasitization on vegetable crops in Lesser Sunda Islands, Indonesia. Biodiversitas, 18(2), 593-600. https://doi.org/10.13057/biodiv/d180221 